\title{
Applicability of commercial clinical chemistry test kits for horse serum
}

\author{
Yoseph Cherinet Megerssa ${ }^{1 *}$ C , Fikru Regassa Gari ${ }^{1}$ and Fanos Tadesse Woldemariyam, ${ }^{1,2}$
}

\begin{abstract}
Objective: Validation of a test method is critical for confirming that the test can generate accurate and precise data. Although commercial biochemical test kits exist there are no specific and validated commercial clinical chemistry test kits designed for horses. The aim of this study was to validate commercial clinical chemistry test kits designed for a human serum for use in horses.

Results: Blood samples were collected from 29 apparently healthy adult male horses and pooled serum was prepared. Validation comprises replication and recovery experiments. Total observable error $\left(\mathrm{TE}_{\mathrm{o}}\right)$, sigma $(\sigma)$ metrics, and quality goal index (QGl) were used to support the validation studies. Intra- and inter-assay variability was $2.05 \%$ and $2.08 \%, 2.26 \%$ and $1.89 \%, 2.4 \%$ and $1.63 \%$, for total cholesterol, urea and total protein, respectively; recovery was $99.46 \%, 97.32 \%$, and $100.1 \%$ for total cholesterol, urea and total protein, respectively. $\mathrm{TE}_{\mathrm{o}} \%$ for the specified analytes was within the total allowable error $\left(\mathrm{TE}_{\mathrm{a}}\right)$. All three analytes satisfied the recommended requirement $(>3 \sigma)$. The $\mathrm{QGl}$ for urea, as it had below $6 \sigma$ was 0.95 indicating imprecision and inaccuracy. The results endorse the suitability of the studied commercial test kits and illustrated the acceptance criteria for horse's serum.
\end{abstract}

Keywords: Clinical Chemistry, Horse, Validation

\section{Introduction}

Clinical laboratory plays a fundamental role in disease diagnosis, assessment of risk for a disease, monitoring to therapy and/or progression of the disease by providing timely data for patient management and disease surveillance [1]. One area in this regard is clinical chemistry laboratory and becomes popular in veterinary medicine [2]. It is indispensable that veterinary clinical laboratories must achieve accurate and precise test results. Clinical laboratory tests performed using an automated clinical chemistry instruments involves calibrators, controls, and reagents [3]. Ensuring the consistency of clinical chemistry laboratory test result is vital to maintain that testing is done right and produces accurate results [4].

\footnotetext{
*Correspondence: yoseph.cherinet@aau.edu.et

${ }^{1}$ Department of Biomedical Sciences, College of Veterinary Medicine

and Agriculture, Addis Ababa University, Addis Ababa, Ethiopia

Full list of author information is available at the end of the article
}

Quality in health care has an immense impact on patient management as approximately $80 \%$ of all diagnosis is made on the basis of laboratory test results [5]. Method validation is one of the important quality mechanisms that are designed to ensure the generation of scientifically valid and useful analytical data [6]. Though all commercial clinical chemistry test kits are validated for their use in medical laboratories, they are also commonly used in veterinary clinical laboratories [7]. It is imperative to conduct partial validation studies, independent of the manufacturer's claim. Partial validation should be made to confirm the analytical procedure is fit for its intended purpose to be eligible for use under actual settings [8]. According to the European Medicines Agency (EMA) guideline on bioanalytical method validation, commercial kits need to be revalidated to ensure that the sample analysis is performed accurately and precisely. Furthermore, a change of biological matrix or species is a reason to perform a partial validation, which can range from the determination of the within-run precision and

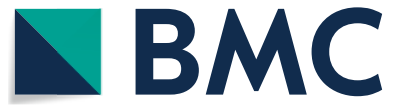

(c) The Author(s) 2021. This article is licensed under a Creative Commons Attribution 4.0 International License, which permits use, sharing, adaptation, distribution and reproduction in any medium or format, as long as you give appropriate credit to the original author(s) and the source, provide a link to the Creative Commons licence, and indicate if changes were made. The images or other third party material in this article are included in the article's Creative Commons licence, unless indicated otherwise in a credit line to the material. If material is not included in the article's Creative Commons licence and your intended use is not permitted by statutory regulation or exceeds the permitted use, you will need to obtain permission directly from the copyright holder. To view a copy of this licence, visit http://creativeco mmons.org/licenses/by/4.0/. The Creative Commons Public Domain Dedication waiver (http://creativecommons.org/publicdomain/ zero/1.0/) applies to the data made available in this article, unless otherwise stated in a credit line to the data. 
accuracy to an almost full validation [9]. Validation is a pre-requisite to perform sample analysis and also key to satisfy regulatory requirements [10].

Clinical chemistry tests are often used for the measurement of analytes in serum and other body fluids. However, the quality of clinical chemistry tests may introduce systematic and random errors. This calls the need for validation of clinical laboratory tests, regardless of its use in diagnostic or research industry [11]. Therefore the aim of the study is to validate commercially available selected clinical chemistry in vitro diagnostic kits: urea, total protein, and total cholesterol designed for a human serum for use in horse serum. The research was the first partial validation study of clinical chemistry test kits in the veterinary clinical laboratory environment. Healthcare professionals and academia in Ethiopia and elsewhere will benefit at large from the findings.

\section{Main text \\ Methods \\ Study design}

The Study design was developed using the American Society of Veterinary Clinical Pathology (ASVCP) guidelines: allowable total error guidelines for biochemistry [11]. Total allowable error $\left(\mathrm{TE}_{\mathrm{a}}\right)$ for biochemical analytes was indicated in the guideline. Sample collection and animal use were approved by the institutional animal research ethics review committee at the Addis Ababa university, College of veterinary medicine and agriculture (Certificate reference no VM/ERC/09/01/12/2020).

\section{Study animals and sampling technique}

The World Organization for Animal Health (OIE) guideline 3.6.6 selection and use of reference samples and panels recommended minimum of 5 samples to prepare serum pool [12]. In addition to computing a statistically valid number of samples as suggested by Bayes SuccessRun Theorem for validation studies $95 \%$ confidence and $90 \%$ reliability used. Therefore $\mathrm{n}=28.4$. We used 29 samples for the study [13]. The study animals were an adult male horse of age ( $\geq 4.5$ years) and whose body condition score 3 were recruited by convenient sampling technique at society for the protection of animals abroad (SPANA) Ethiopia clinic. Apparently healthy horses from owners who were consent after being informed about the purpose of the study were physically examined. Horses with a history of medication excluded due to the possible impact of drugs on analysis.

\section{Blood collection and processing}

Blood samples from study animals were collected by a veterinarian from the jugular vein using the standard operating procedure. The blood was allowed to clot at room temperature for between $30 \mathrm{~min}$ and serum was separated from the red blood cells by centrifugation at $1200 \times g$ for $10 \mathrm{~min}$ at $4{ }^{\circ} \mathrm{C}$. Serum was immediately transferred to polypropylene tubes (Eppendorf Safe-Lock tubes) and stored at $-20^{\circ} \mathrm{C}$ until measurements. Samples were collected during two weeks in January 2020. Pooled serum samples were created by mixing equal volumes of individual serum then homogenized using an agitator for $10 \mathrm{~min}$ at $180 \mathrm{rpm}$. After homogenization aliquots of the homogeneous pool were divided into twenty portions to avoid the effect of repeated thawing and freezing.

\section{Analytical validation}

To examine the accuracy and precision of commercial clinical chemistry kits (JOURILABS diagnostics reagents and stains-Addis Ababa, Ethiopia) total cholesterol, urea, and total protein were used and analysis of the parameters was determined by the methods/techniques described as follows: urea by kinetic urease/GLDH (Glutamate dehydrogenase), total protein by biuret and total cholesterol by CHOD-PAP (cholesterol peroxidase4-aminophenazone). The procedure of validation was adopted from the Westgard JO method validation protocol. The analytical validation comprises recovery studies for accuracy and replication experiments for precision [14]. The tests were performed on semi-automated chemistry analyzer (EMP-168 biochemical analyzer Chengdu Empsun Medical Technology Co., Ltd. China).

\section{Replication experiments}

Precision was assessed by evaluating the intra- and interassay variability using the pooled serum. Intra-assay variability (repeatability) was determined by measuring total cholesterol, urea, and total protein in the same sample 20 times sequentially within a single run. Interassay variability (reproducibility) was determined by analysing the same sample in duplicate for 20 consecutive days. To avoid the effect of repeated thawing and freezing, the samples used for the determination of inter-assay were aliquot and stored at $-20{ }^{\circ} \mathrm{C}$ until use [15].

\section{Recovery experiments}

The spike and recovery (SAR) assessment is essential for the analysis and accuracy evaluation of the method for particular sample types. Spike and recovery assay is used to determine whether the detection of an analyte is affected by biological sample matrix and differences in the standard curve diluent $[16,17]$. Serum samples were spiked with different concentrations of standard Total cholesterol $(26 \mathrm{mg} / \mathrm{dl} ; 0.1 \mathrm{ml}$ of $200 \mathrm{mg} / \mathrm{dl}$ standard solution was spiked in $1 \mathrm{ml}$ serum) Urea $(9.1 \mathrm{mg} / \mathrm{dl} ; 0.1 \mathrm{ml}$ of $100 \mathrm{mg} / \mathrm{dl}$ standard solution was spiked in $1 \mathrm{ml}$ serum) 
Table 1 Precision of the pooled serum for total cholesterol, urea and total protein

\begin{tabular}{|c|c|c|c|c|c|c|}
\hline \multirow{2}{*}{$\begin{array}{l}\text { Precision } \\
\text { Parameters }\end{array}$} & \multicolumn{3}{|c|}{ Intra-assay $(\mathrm{N}=20)$} & \multicolumn{3}{|c|}{ Inter-assay $(\mathrm{N}=20)$} \\
\hline & Mean & SD & CV & Mean & SD & CV \\
\hline Total cholesterol & 80.3 & 1.65 & 2.05 & 80.4 & 1.67 & 2.08 \\
\hline Urea & 80.3 & 1.82 & 2.26 & 80.4 & 1.52 & 1.89 \\
\hline Total protein & 6.25 & 0.15 & 2.4 & 6.13 & 0.1 & 1.63 \\
\hline
\end{tabular}

and total protein $(1.1 \mathrm{mg} / \mathrm{dl} ; 0.1 \mathrm{ml}$ of $12 \mathrm{mg} / \mathrm{dl}$ standard solution was spiked in $1 \mathrm{ml}$ serum).

\section{Quality requirement}

\section{Total allowable error $\left(T E_{\mathrm{a}}\right)$}

The performance of tests was assessed by computing $\mathrm{TE}_{\mathrm{obs}}(\%)$ and $\sigma$ values. $\mathrm{TE}_{\mathrm{obs}}(\%)=2 \times \mathrm{CV}+$ bias (\%), Bias $(\%)=[$ (target - measured $) \div$ target $] \times 100 \%$, where "target" is the spiked value for analyte and "measured" is the measured analyte concentration. The CV and bias (\%) values from inter-assay were used to calculate $\mathrm{TE}_{\mathrm{obs}}$ (\%). If $\mathrm{TE}_{\mathrm{obs}}(\%)$ is less than $\mathrm{TE}_{\mathrm{a}}(\%)$; the quality requirement passes and no further action needed. The $\mathrm{TE}_{\mathrm{a}}(\%)$ employed in this study was total cholesterol: $20 \%$, Urea: $12 \%$ and total protein: $10 \%$ adopted from the American society of veterinary clinical pathology (ASVCP) guidelines: allowable total error guidelines for biochemistry [11].

\section{Sigma metrics ( $\sigma$ )}

Sigma value $(\sigma)$ calculated as $\sigma=\left[\mathrm{TE}_{\mathrm{a}}(\%)-\right.$ Bias $(\%)] \div \mathrm{CV}$. The interpretations of the $\sigma$ values are $>2$ : Poor, $>$ 3: Marginal, $>4$ : Good, $>$ 5: Excellent, and $>6$ : World-class. Acceptable performance of a method is declared if $\mathrm{TE}_{\mathrm{obs}}<\mathrm{TE}_{\mathrm{a}}[18,19]$.

\section{Quality goal index ratio (QGI)}

QGI describes the extent to which both precision and bias meet their respective quality. This is used to find the reasons for the lower $\sigma$ in analytes whether the problem is due to imprecision or inaccuracy or both. QGI ratio calculated as $\mathrm{QGI}=\mathrm{Bias} / 1.5 \times \mathrm{CV} \%$. The interpretations of the QGI with low $\sigma$ values $(<6)$ are QGI $<0.8$ shows imprecision, QGI 0.8-1.2 shows both imprecision and inaccuracy and QGI > 1.2 depicts inaccuracy [20].

\section{Data analysis}

Statistical analyses were performed using IBM SPSS 20. The normality distribution of the data was tested using the Kolmogorov-Smirnov test prior to statistical analysis. Data of accuracy from bias and precision from intraassay and inter-assay CVs were estimated using routine descriptive statistical procedures.

\section{Results}

The present study validated total cholesterol, urea, and total protein test kits using pooled serum collected from 29 apparently healthy horses. Intra-assay precision was done by repeated measurements of pooled serum under specific and identical conditions on the same day. For inter-assay repeatability, the pooled serum was frozen in separate vials at $-20{ }^{\circ} \mathrm{C}$, thawed at room temperature, and assayed on 20 consecutive days. The data generated was calculated in terms of mean SD and CV is presented in Table 1.

To assess accuracy, a recovery method based on standard addition was used to evaluate the ability of the assay to recover the amount of analyte added to baseline pooled serum. The baseline pooled serum was obtained by the dilution of pooled serum with distilled water. While the spiking was done by the addition of standard solutions to pooled serum then both diluted and spiked pooled serum was assayed on 5 replicates and the average value is depicted in Table 2 .

The $\mathrm{TE}_{\mathrm{o}}$ was expresses by combining random error (\% CV) from the precision and systematic error (bias) from the accuracy estimation. The $\mathrm{TE}_{\mathrm{o}}$ for the specified analytes was within the $\mathrm{TE}_{\mathrm{a}}$ indicated in ASVCP guidelines (Table 3). The quality of testing also assessed by sigma metrics and all analytes satisfied the recommended requirement ( $>3$ sigma values). Total cholesterol and total protein showed $>6 \sigma$ zone (world-class quality) while urea showed $4.9 \sigma$ (Good class quality). The QGI for urea, as it had below $6 \sigma$ was 0.95 falling in

Table 2 Recovery for the pooled serum for total cholesterol, urea and total protein

\begin{tabular}{llllll}
\hline Analyte & Addition & Dilution & Observed & Expected & $\begin{array}{l}\text { Recovery } \\
\text { (\%) }\end{array}$ \\
\hline $\begin{array}{l}\text { Total cho- } \\
\text { lesterol }\end{array}$ & 93.6 & 75.5 & 18.1 & 18.2 & 99.46 \\
$\begin{array}{l}\text { Urea } \\
\begin{array}{l}\text { Total pro- } \\
\text { tein }\end{array}\end{array}$ & 7.49 & 6.38 & 1.11 & 1.1 & 100.1 \\
\hline
\end{tabular}


Table 3 The sigma metrics and quality goal index ratio for Total cholesterol, Urea, and Total Protein

\begin{tabular}{|c|c|c|c|c|c|c|c|}
\hline Analyte & Bias (\%) & CV (\%) & $\mathrm{TE}_{\mathrm{o}}(\%)$ & $\mathrm{TE}_{\mathrm{a}}(\%)$ & Sigma & QGI & Problem \\
\hline Total cholesterol & 0.54 & 2.08 & 4.7 & 20 & 9.34 & 0.17 & None \\
\hline Urea & 2.68 & 1.89 & 6.46 & 12 & 4.9 & 0.95 & $\begin{array}{c}\text { Impression } \\
\text { and inac- } \\
\text { curacy }\end{array}$ \\
\hline Total protein & 0.1 & 1.63 & 3.36 & 10 & 6.1 & 1.37 & None \\
\hline
\end{tabular}

the range of $0.8-1.2$ shows both imprecision and inaccuracy (Table 3).

\section{Discussion}

This study was undertaken to determine whether commercial clinical chemistry test kits are applicable to test analytes in horse serum. There are few studies on the validation of commercial kits and this study is the first in a veterinary laboratory environment in Ethiopia. Our study focused on the recovery and repeatability experiments which then followed by calculating sigma values and quality goal index for three analytes namely total cholesterol, urea, and total protein in horse serum.

According to the findings of the study for the intraassay and inter-assay precision to be accepted, SD must not exceed $0.25 \times \mathrm{TE}_{\mathrm{a}}$ and $0.33 \times \mathrm{TE}_{\mathrm{a}}$ respectively for the given analyte $[15,21]$. In this regard intra-assay and inter-assay precision for total cholesterol demonstrated $<5 \%$ and $<6.6 \%$, urea $<3 \%$ and $3.96 \%$, total protein $<2.5 \%$ and $<3.3 \%$. The precision profile representing the $\% \mathrm{CV}$ is within the established acceptance criteria.

The findings of recovery percentages were between expected values and measured values demonstrate that all tests were within the acceptance range of $80-120 \%$ $[22,23]$. Besides the error observed was less than the allowable error assigned for the analytes [11]. Quality index ratios for total cholesterol and protein indicate no problem in terms of accuracy and precision while in case of urea the root cause for impression and inaccuracy should be investigated before it routinely used as the quality of the test in such cases cannot be assured [24, 25].

\section{Conclusion}

Validation of the bioanalytical methods should be an integral part in laboratory management and health care. Commercial clinical chemistry test kits are often validated by the manufacturers. There is a need to verify the validity of the test kits before applying to diagnostic and research purposes particularly when the sample matrix is different. The study demonstrated that the commercial kits used in the study satisfied the acceptable criteria and recommended its use for horse serum. However, a full validation study of the clinical chemistry test kits for their fitness in a number of laboratories and clinical decision limit is recommended.

\section{Limitations}

- The study was unable to conduct comparison studies due to financial constraints.

- The study was unable to conduct validation on high and low concentration due to the unavailability of materials.

- The study was limited to conduct on male horse.

\section{Abbreviations}

AAU: Addis Ababa University; ASVCP: American Society of Veterinary Clinical Pathology; CV: Coefficient of variation; EMA: European Medicines Agency; OIE: World Organisation for Animal Health; QGI: Quality goal index; SAR: Spike and recovery; SD: Standard deviation; SPANA: Society for Protection of Animal's Abroad; $\mathrm{TE}_{\mathrm{a}}$ : Total allowable error; $\mathrm{TE}_{\mathrm{o}}$ : Total observed error.

\section{Acknowledgements}

The authors would like to acknowledge Mr. Tibebu Ashine (B.Sc., MPH) and Dr. Hana Zewdu (DVM, M.Sc.) staffs of SPANA-Ethiopia for their cooperation during sample collection. Corresponding author also acknowledges Dr. Bineyam Taye (B.Sc., MPH, Ph.D., Associate Professor at Colgate University, NY, USA) who stirred the topic of method validation during graduate studies at AAU.

\section{Authors' contributions}

YC conceived and design the study, responsible for data integrity, analysis, and interpretation. YC, FR, and FT drafted and revised the manuscript. All authors read and approved the final manuscript.

\section{Funding}

This research was supported by the Addis Ababa University (AAU) research and technology transfer office through adaptive problem solving research fund (Reference No: RD/LT/PY-034/2019, Dated 26-November-2019). AAU covers all expenses and played administrative role during procurement of items used in research.

Availability of data and materials

The data used to support this study are available from the corresponding author on request.

\section{Ethics approval and consent to participate}

The study obtained research ethical clearance approved by the institutional animal research ethics committee at the Addis Ababa University, College 
of veterinary medicine and agriculture (Certificate Reference No VM/ ERC/09/01/12/2020)

\section{Consent to publish}

Not applicable.

\section{Competing interests}

The authors declare that no competing interests to declare.

\section{Author details}

${ }^{1}$ Department of Biomedical Sciences, College of Veterinary Medicine and Agriculture, Addis Ababa University, Addis Ababa, Ethiopia. ${ }^{2}$ Department of Biosystems, Division of Animal and Human Health Engineering, Laboratory of Host-Pathogen interaction, KU Leuven, Leuven, Belgium.

Received: 5 October 2020 Accepted: 24 December 2020

Published online: 07 January 2021

\section{References}

1. WHO Regional Committee for Africa Resolution AFR/RC58/R2: strengthening public health laboratories in the WHO African region: a critical need for disease control. In: WHO Regional Committee for Africa. Final Report: 58th Session of the WHO Regional Committee for Africa. WHO Regional Office for Africa, Brazzaville 2008; p. 11-13.

2. Rishniw Mark, Pion Paul D, Maher Tammy. The quality of veterinary in-clinic and reference laboratory biochemical testing. Vet Clin Pathol. 2012;41(1):92-109.

3. Cho MC, Kim SY, Jeong TD, Lee W, Chun S, Min WK. Statistical validation of reagent lot change in the clinical chemistry laboratory can confer insights on good clinical laboratory practice. Ann Clin Biochem. 2014;51(6):688-94.

4. Miller WG, Erek A, Cunningham TD, Oladipo O, Scott MG, Johnson RE. Commutability limitations influence quality control results with different reagent lots. Clin Chem. 2011;57(1):76-83.

5. Agarwal R, Chaturvedi S, Chhillar N, Goyal R, Pant I, Tripathi CB. Role of intervention on laboratory performance: evaluation of quality indicators in a Tertiary Care Hospital. Indian J Clin Biochem. 2012;27:61-8.

6. Thompson M, Ellison SLR, Wood R. Harmonized guidelines for singlelaboratory validation of methods of analysis. IUPAC technical report. Pure Appl Chem. 2002;74(5):835-55.

7. Pasciu V, Baralla E, Nieddu Maria, Succu S, Porcu C, Leoni GG, Sechi P, Bomboi GC, Berlinguer F. Commercial human kits' applicability for the determination of biochemical parameters in sheep plasma. J Vet Med Sci. 2019;81(2):294-7.

8. Guidance for industry bioanalytical method validation U.S. Department of Health and Human Services food and drug administration centre for drug evaluation and research (CDER) Center for Veterinary medicine (CVM). 2001. http://academy.gmp-compliance.org/guidemgr/files/4252FNL.PDF. Accessed 14 Dec 2020

9. EMA Guideline on Bioanalytical Method Validation 2011. https://www. ema.europa.eu/en/documents/scientific-guideline/guideline-bioanalyti cal-method-validation_en.pdf. Accessed 14 Dec 2020.
10. Mano Y. Method validation studies and an inter-laboratory cross validation study of lenvatinib assay in human plasma using LC-MS/MS. Pract Lab Med. 2018;12:e00103.

11. Harr KE, Flatland B, Nabity M, Freeman KP. ASVCP guidelines: allowable total error guidelines for biochemistry. Vet Clin Pathol. 2013;42(4):424-36.

12. OIE Validation Guidelines 2014 [Internet] Selection and use of reference samples and panels. https://www.oie.int/fileadmin/Home/eng/Healt h_standards/aahm/current/GUIDELINE_3.6.6_REFERENCE_SAMPLES.pdf. Accessed 14 Dec 2020

13. Ferryanto L. Statistical sampling plan for design verification \& validation of medical devices. J Valid Tech. 2015;21(1):1-9.

14. Westgard JO. Method validation-the experimental plan. In: Westgard JO, editor. Basic Method Validation. 3rd ed. Madison: Westgard QC, Inc; 2008. p. 61-9.

15. Westgard JO. Method validation-the replication experiment. In: Westgard JO, editor. Basic Method Validation. 3rd ed. Madison: Westgard QC, Inc; 2008. p. 114-22.

16. Lee JW. Fit-for-purpose method development and validation for successful biomarker measurement. Phram Res. 2006;23(2):312-28.

17. Westgard JO. Method validation-the interference and recovery experiments. In: Westgard JO, editor. Basic Method Validation. 3rd ed. Madison: Westgard QC, Inc; 2008. p. 154-66.

18. Nevalainen D, Berte L, Kraft C, Leigh E, Picaso L, Morgan T. Evaluating laboratory performance on quality indicators with the six sigma scale. Arch Pathol Lab Med. 2000;124(4):516-9.

19. Westgard JO. A method evaluation decision chart (MEDx chart) for judging method performance. Clin Lab Sci. 1995;8:277-83.

20. Westgard JO, Westgard SA. An assessment of $\sigma$ metrics for analytic quality using performance data from proficiency testing surveys and the CLIA criteria for acceptable performance. J Vet Diagn Invest. 2008;20:536-44.

21. Daniel W, Anders K, John W, Jan S, Kristen M. Evaluation of precision performance of quantitative measurement methods; Approved guideline. NCCLS Document EP5-A2. 2004;24(25):7-13.

22. Andreasson $U$, Perret-Liaudet $A$, van van Waalwijk Doorn $\sqcup C$, , Blennow K, Chiasserini D, Engelborghs S, Fladby T, Genc S, Kruse N, Kuiperij HB, Kulic L, Lewczuk P, Mollenhauer B, Mroczko B, Parnetti L, Vanmechelen E, Verbeek MM, Winblad B, Zetterberg H, Koel-Simmelink M, Teunissen CE. A practical guide to immunoassay method validation. Front Neurol. 2015;19(6):179.

23. Valentin MA, Ma S, Zhao A, Legay F, Avrameas A. Validation of immunoassay for protein biomarkers: bioanalytical study plan implementation to support pre-clinical and clinical studies. J Pharm Biomed Anal. 2011;55(5):869-77.

24. Westgard JO. Six sigma quality design and control. 2nd ed. Madison: Westgard QC Inc.; 2006

25. Westgard JO, Westgard SA. The quality of laboratory testing today an assessment of sigma metrics for analytic quality using performance data from proficiency testing surveys and the CLIA Criteria for Acceptable Performance. J Clin Pathol. 2006;125:343-4.

\section{Publisher's Note}

Springer Nature remains neutral with regard to jurisdictional claims in published maps and institutional affiliations.
Ready to submit your research? Choose BMC and benefit from:

- fast, convenient online submission

- thorough peer review by experienced researchers in your field

- rapid publication on acceptance

- support for research data, including large and complex data types

- gold Open Access which fosters wider collaboration and increased citations

- maximum visibility for your research: over 100M website views per year

At BMC, research is always in progress.

Learn more biomedcentral.com/submissions 